\title{
Quantitative Determination of Four Angiotensin-II-Receptor Antagonists in Presence of Hydrochlorothiazide by a Gradient Technique HPLC in their Pharmaceutical Preparations
}

\author{
Hani M. Hafez ${ }^{1 *}$, Lobna M. Abdelaziz², Abdullah A. Elshanawane ${ }^{2}$ and Magda M. Kamal ${ }^{3}$ \\ ${ }^{1}$ Bachelor degree of Pharmaceutical Science, Zagazig University, Zagazig, Egypt \\ ${ }^{2}$ Assistant professor of Medicinal Chemistry, Medicinal Chemistry Department Faculty of pharmacy, Zagazig University, Zagazig, Egypt \\ ${ }^{3} \mathrm{PhD}$ in Chemistry, Nancy University, France
}

\begin{abstract}
Losartan potassium, Valsartan, Telmisartan and Irbesartan are angiotensin-II-receptor antagonists (ARA II) group which used in treatment of hypertension alone or in combination with other drugs mainly Hydrochlorothiazide. A gradient HPLC method was developed for the assay of several ARAll in presence of Hydrochlorothiazide. The method was performed by reversed phase high performance liquid chromatography using a mobile phase $0.025 \mathrm{M}$ potassium dihydrogen phosphate $(\mathrm{pH} 6.0)$ : acetonitrile $=80: 20 \%$ with detection at $220 \mathrm{~nm}$ on an ACE C18 column $(250 \mathrm{~mm} \times 4.6 \mathrm{~mm}, 5 \mu \mathrm{m})$ at flow rate $1.5 \mathrm{ml} / \mathrm{min}$ in a gradient manner. The proposed method was validated in terms of linearity, accuracy, precision and limits of detection and quantitation.
\end{abstract}

Keywords: Hydrochlorothiazide; Losartan potassium; Irbesartan; Valsartan; Telmisartan

\section{Introduction}

Angiotensin antagonists are the first major innovation in essential hypertension management as a first-line treatment. Angiotensin II receptor antagonists (ARA II) have been developed to specifically and selectively block the AT1 receptor of the rennin angiotensin system by displacing angiotensin II from it [1]. Losartan potassium, Telmisartan, Irbesartan and Valsartan are highly selective, non-peptide angiotensinII receptor antagonist s (ARA-II). They are effective agents for the treatment of hypertension and heart failure either alone or together with diuretics or recently with other antihypertensive drugs [2]. So, it is necessary to develop a validated analytical method for assay of ARAII in combination with hydrochlorothiazide in its pharmaceutical preparations. Literature review revealed that USP described RP-HPLC methods for assay of Losartan potassium, Valsartan and ion pair HPLC for Irbesartan and Telmisartan. It described gradient RP-HPLC methods for assay of Losartan potassium, Valsartan in combination with hydrochlorothiazide and a gradient ion pair HPLC for Irbesartan in combination with hydrochlorothiazide [3]. BP described a potentiometric titration for assay of Losartan potassium, Irbesartan, Telmisartan and Valsartan [4]. Some methods have been published for simultaneous determination of studied ARA-II-drugs separately in combination with hydrochlorothiazide in its pharmaceutical preparations [5-15]. EIPICO Company described a RP-HPLC method for analysis of Losartan potassium and hydrochlorothiazide (50/12.5 mg) tablets. Analysis was performed on a Hypersil C18 column using mobile phase consisted of a mixture of acetonitrile and phosphate buffer ( $\mathrm{pH} 3.5 ; 0.05 \mathrm{M})(50: 50 \% \mathrm{v} / \mathrm{v})$ and detector was set at $220 \mathrm{~nm}$ [16] other methods have been reported for determination of only ARAII drugs [17-19]. Only one method has been established to assay ARAII and hydrochlorothiazide by electrophoresis [20] but this technique is less available in pharmaceutical companies than HPLC-UV and more expensive so, it is preferable that the developed method is HPLC-UV, the most spreadable apparatus in pharmaceutical companies. Our recent method is characterized by a simplicity, accuracy, preciseness and sensitivity.
Hydrochlorothiazide is $2 \mathrm{H}-1,2,4$-Benzothiadiazine-7-sulfonamide, 6-chloro-3, 4-dihydro 1, 1-dioxide; Hydrochlorothiazide is the most famous thiazide diuretics. Losartan potassium is 2-butyl-4chloro-1-[[2'-(1H-tetrazol-5-yl)[1,1'-biphenyl]-4-yl]methyl]-1H-imidazole-5-methanol monopotassium salt, is the first member of a new class of non-peptide angiotensin II receptor antagonist .Irbesartan is 2-butyl-3-[p-(o-1H-tetrazol-5-ylphenyl) benzyl]-1, 3-diazaspiro [4.4] non-1-en-4-one. It is an orally active specific angiotensin II receptor antagonist used, as a hypotensive agent does not require biotransformation into an active form. Valsartan is $\mathrm{N}$-(1-oxopentyl)- $\mathrm{N}$-[ [2- $(1 \mathrm{H}-$ tetrazol-5-yl) [1, 1-biphenyl]-4-yl] methyl]-l-valine. Valsartan is a potent, highly selective, and orally active antagonist at the angiotensin II AT1- receptor. Telmisartan is 4-((2-n-propyl-4-methyl-6-(1-methylbenzimidazol-2-yl)-benzimidazol-1-yl) methyl) biphenyl-2-Carboxylic acid (Figure 1).

\section{Experiment}

\section{Instrumentation}

Balance: KERN model 870-13, Instrument Kern Balance, Supplied from Kern, Germany Model/Type/P 870-13, Serial No: 84444

High performance liquid chromatography: Consisting of instrumental

(a) AGILENT 1200 Quaternary pump.

*Corresponding author: Hani M. Hafez, Bachelor degree of Pharmaceutical Science, Zagazig University, Zagazig, Egypt, Tel: 020113231458; E-mail: hanyhaf_1982@yahoo.com

Received July 15, 2012; Accepted September 03, 2012; Published September 07, 2012

Citation: Hafez HM, Abdelaziz LM, Elshanawane AA, Kamal MM (2012) Quantitative Determination of Four Angiotensin-II-Receptor Antagonists in Presence of Hydrochlorothiazide by a Gradient Technique HPLC in their Pharmaceutical Preparations. Pharmaceut Anal Acta 3:167. doi:10.4172/21532435.1000167

Copyright: $\odot 2012$ Hafez HM, et al. This is an open-access article distributed under the terms of the Creative Commons Attribution License, which permits unrestricted use, distribution, and reproduction in any medium, provided the original author and source are credited. 
Citation: Hafez HM, Abdelaziz LM, Elshanawane AA, Kamal MM (2012) Quantitative Determination of Four Angiotensin-II-Receptor Antagonists in Presence of Hydrochlorothiazide by a Gradient Technique HPLC in their Pharmaceutical Preparations. Pharmaceut Anal Acta 3:167. doi:10.4172/2153-2435.1000167

Page 2 of 7

a-

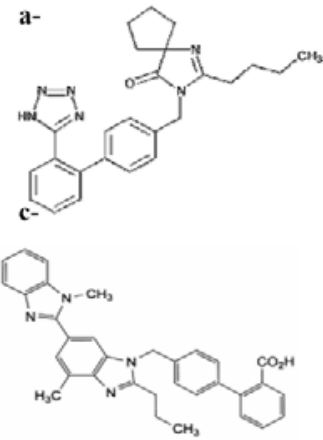

b-

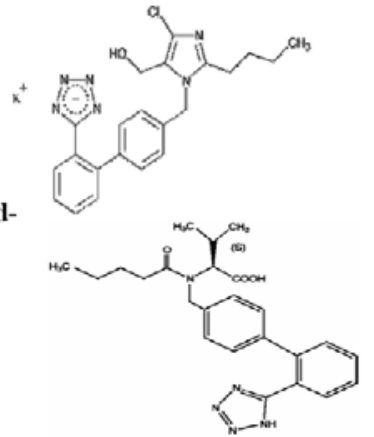<smiles>CCNS(=O)(=O)c1cc2c(cc1Cl)NCNS2(=O)=O</smiles>

Figure 1: Structures of a- Irbesartan b- Losartan potassium c- Telmisartan Valsartan e- Hydrochlorothiazide.

(b) AGILENT 1200 Diode Array detector (DAD).

(c) AGILENT 1200 Auto sampler (injector).

(d) Column: ACE column dimension $(250 \times 4.6) \mathrm{mm}$ particle size $5 \mu$ Supplied from ACE.

(e) The system equipped by Agilent chemistation PC program.

PH meter: Metrohm.

Stirrer: Fischer scientific UK.

\section{Chemicals and reagents}

All reagents used were of analytical grade or HPLC grade. Potassium dihydrogen phosphate, orthophosphoric acid and Sodium hydroxide $(\mathrm{NaOH})$ were supplied by (Merck, Darmstadt, Germany), Acetonitrile and Methanol HPLC grade were supplied by (Fischer scientific, U.K.) and Distilled water.

(Note: The water used in all the experiments was obtained from Milli-RO and Milli-Q systems (Millipore, Bedford, MA).

Irbesartan, Losartan potassium, Telmisartan, Valsartan and Hydrochlorothiazide working standard powders were kindly supplied by Egyptian international pharmaceutical industries company (EIPICO) (10 ${ }^{\text {th }}$ Ramadan, Egypt), and were used without further purification.

\section{Pharmaceutical preparation}

X-tension plus tablets October pharma /EPCP (Egypt) contain (150 mg Irbesartan + $12.5 \mathrm{mg}$ Hydrochlorothiazide) per tablet B.NO: E0230311. Losazide tablets (EIPICO, Egypt) contain (50 mg Losartan potassium $+12.5 \mathrm{mg}$ Hydrochlorothiazide) per tablet B.NO:1002445. Micardis plus tablets (Boehringer Ingelheim Company, Germany) contain ( $80 \mathrm{mg}$ Telmisartan $+12.5 \mathrm{mg}$ Hydrochlorothiazide) per tablet B.NO:908577. Disartan CO 80 tablets (Global Napi Pharmaceuticals GNP, Egypt) contain ( $80 \mathrm{mg}$ Valsartan $+12.5 \mathrm{mg}$ Hydrochlorothiazide) per tablet B.NO: 921501.

\section{Chromatographic condition}

Mobile phase: A mixture of potassium dihydrogen phosphate buffer ( $\mathrm{pH}$ 6.0, 0.025M) - acetonitrile (80\%:20\%, V/V). (Gradient elution)(Table 1)

Phosphate buffer $(0.025 \mathrm{M})$ was prepared by dissolving $3.6 \mathrm{~g}$ potassium dihydrogen phosphate in approximately $950 \mathrm{ml}$ distilled water. The $\mathrm{pH}$ was adjusted to 6.0 with $1 \mathrm{M} \mathrm{NaoH}$ and water was added to $1000 \mathrm{ml}$.

Column: ACE RP-C18 supplied from ACE.

Detector: was set at $220 \mathrm{~nm}$.

Flow rate: $1.5 \mathrm{ml} / \mathrm{min}$.

Column temperature: $40 \mathrm{C}^{\circ}$.

Injection volume: $50 \mu \mathrm{l}$.

The mobile phase was filtered through a $0.45 \mu \mathrm{l}$ Nylon membrane filter (Millipore, Milford, MA, USA) under vacuum and degassed by ultrasonication (Cole Palmer, Vernon Hills, USA) before usage.

\section{Preparation of stock standard solutions}

Stock standard solutions containing $(1.25,1.5,0.5,0.8,0.8 \mathrm{mg} / \mathrm{ml})$ of Hydrochlorothiazide, Irbesartan, Losartan potassium, Telmisartan, Valsartan respectively were prepared by dissolving $(12.5,150,50,80$, $80 \mathrm{mg}$ ) of each in methanol in $100 \mathrm{ml}$ volumetric flask respectively. It was then sonicated for 15 minutes and the final volume of solutions was made up to $100 \mathrm{ml}$ with methanol to get stock standard solutions.

\section{Preparation of calibration plot (working standard solutions)}

To construct calibration plots, The stock standard solutions were diluted with the mobile phase to prepare working solutions in the concentration ranges $(2.5-15,30-180,10-60,16-96,16-96 \mu \mathrm{l} / \mathrm{ml})$ for Hydrochlorothiazide, Irbesartan, Losartan potassium, Telmisartan and Valsartan respectively. Each solution $(n=5)$ was injected in triplicate and chromatographed under the mentioned conditions above. Linear relationships were obtained when average drug standard peak area were plotted against the corresponding concentrations for each drug. Regression equation was computed.

\section{Sample preparation}

A composite of ten $X$-tension plus tablet, Losazide tablet, Disartan CO 80 capsule and Micardis plus tablet were prepared by grinding them to a fine, uniform size powder, triturated using mortar and pestle.

After calculating the average tablet weight, amounts of powder equivalent to $(2.5,150,50,80$ and $80 \mathrm{mg})$ for Hydrochlorothiazide, Irbesartan, Losartan potassium, Telmisartan and Valsartan respectively of each type of tablets were accurately weighed and transferred separately to $100 \mathrm{ml}$ volumetric flasks respectively. Solutions were sonicated for $15 \mathrm{~min}$ and the solutions were then filtered through 0.45 lm Nylon membrane filters (Millipore, Milford, MA, USA). Aliquots of appropriate volume $(10 \mathrm{ml})$ were transferred to $100 \mathrm{ml}$ calibrated flasks

\begin{tabular}{|c|c|c|}
\hline Time $(\min )$ & Buffer $\%$ & Acetonitrile $\%$ \\
\hline 0 & 20 & 80 \\
\hline 5 & 35 & 65 \\
\hline 15 & 35 & 65 \\
\hline 16 & 20 & 80 \\
\hline 17 & 20 & 80 \\
\hline \multicolumn{2}{|c|}{ Table1: Time table of validated gradient method. } \\
\hline
\end{tabular}


Citation: Hafez HM, Abdelaziz LM, Elshanawane AA, Kamal MM (2012) Quantitative Determination of Four Angiotensin-II-Receptor Antagonists in Presence of Hydrochlorothiazide by a Gradient Technique HPLC in their Pharmaceutical Preparations. Pharmaceut Anal Acta 3:167. doi:10.4172/2153-2435.1000167

Page 3 of 7

and diluted to volume with mobile phase to furnish the mentioned concentration above. The diluted solutions were analyzed under optimized chromatographic conditions and chromatogram is depicted in (Figure 2).

\section{Method Validation}

\section{Specificity}

Specificity of the method was evaluated by assessing whether excipients present in the pharmaceutical formulations interfered with the analysis or not [21]. A placebo for each tablet was prepared by mixing the respective excipients and solutions were prepared by following the procedure described in the section of sample preparation. The commonly used tablet excipients did not interfere with the method. The diluent chromatogram in (Figure 3) shows that the tablet diluent has negligible contribution after the void volume at the method detection wavelength of $220 \mathrm{~nm}$

The method were also evaluated by assessing whether degradation products present in the pharmaceutical formulations interfered with the analysis, obtained from stress studies involving acid, base, peroxide and heat as well as analysis of samples stored under ICH stability conditions. Chromatograms are also shown in (Figure 3) to demonstrate method specificity.

\section{Linearity and range}

The linearity of the method was evaluated by analyzing different concentration of the drugs. According to $\mathrm{ICH}$ recommendations [21] at least five concentrations must be used. In this study five Concentrations were chosen, in the ranges $(2.5-15,30-180,10-60,16-96$, and $16-96 \mu \mathrm{l} / \mathrm{ml}$ ) corresponding levels of $20-120 \% \mathrm{w} / \mathrm{w}$ of the nominal analytical concentration for Hydrochlorothiazide, Irbesartan, Losartan potassium, Telmisartan and Valsartan respectively. The linearity of peak area responses versus concentrations was demonstrated by linear least square regression analysis. The linear regression equations were $\{\mathrm{Y}=223.09 \mathrm{X}+4.000(\mathrm{r}=0.9999), \mathrm{Y}=122.54 \mathrm{X}+0.8806(\mathrm{r}=1.0)$, $\mathrm{Y}=138.95 \mathrm{X}+9.9936(\mathrm{r}=1.0), \mathrm{Y}=197.86 \mathrm{X}+120.99(\mathrm{r}=0.9997)$, $\mathrm{Y}=122.07 \mathrm{X}+33.45(\mathrm{r}=1.0)\}$ for Hydrochlorothiazide, Irbesartan, Losartan potassium, Telmisartan and Valsartan respectively. Where $\mathbf{Y}$ is the peak area of standard solution and $\mathbf{X}$ is the drug concentration.

\section{Precision}

The precision of the assay was investigated by measurement of both repeatability and Intermediate precision.

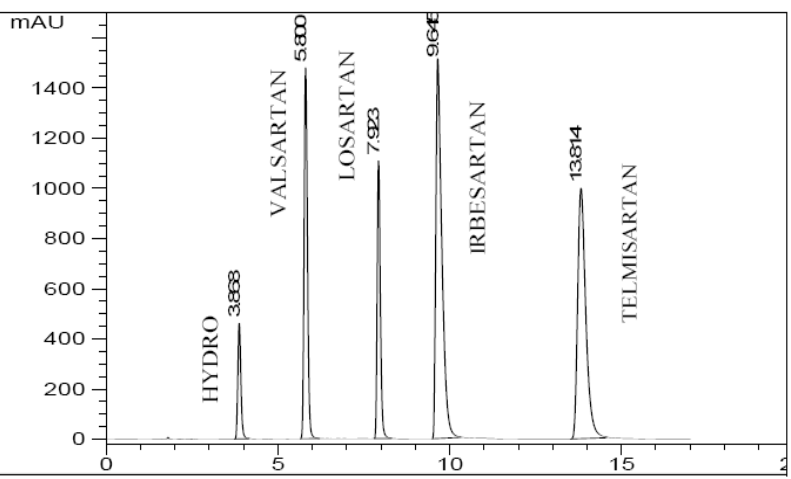

Figure 2: Typical HPLC chromatograms obtained from $50 \mu \mathrm{l}$ injections of Hydrochlorothiazide (3.86 min.), Valsartan (5.8 min.), Losartan potassium (7.92 min.), Irbesartan (9.64 min.) and Telmisartan (13.81 min.) respectively under optimized chromatographic conditions.

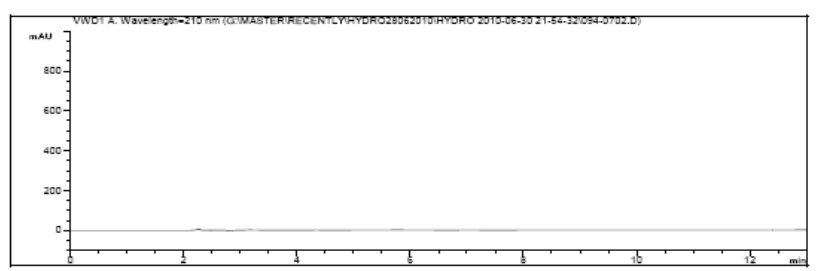

a- tablet placebo under optimized chromatographic conditions
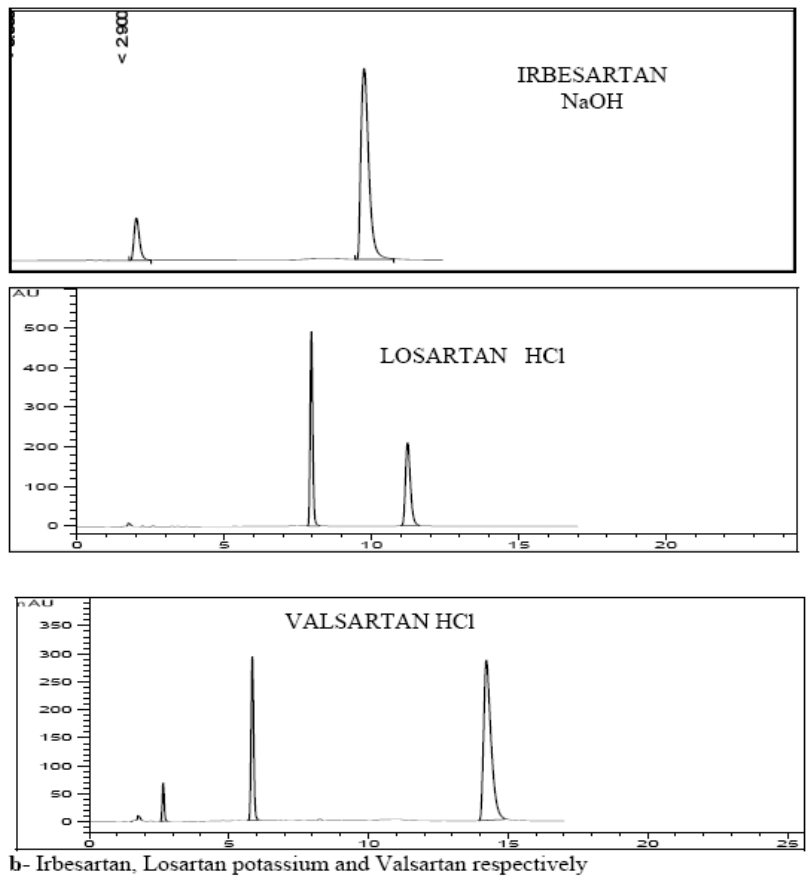

Figure 3: Typical HPLC chromatograms obtained from $50 \mu$ injections of a- tablet placebo under optimized chromatographic conditions b- Irbesartan, Losartan potassium and Valsartan respectively obtained from stress studies involving acid, base and heat as well as analysis of samples stored under ICH stability conditions under optimized chromatographic conditions.

Repeatability: Repeatability was investigated by injecting 6 determinations at $100 \%$ of the test concentration percentage RSD were calculated in Table 2.

Intermediate precision: In the inter-day studies, standard and sample solutions prepared as described above, were analyzed in triplicate on three consecutive days at $100 \%$ of the test concentration and percentage RSD were calculated (Table 3 ).

\section{Accuracy}

Accuracy was assessed using 9 determinations over 3 concentration levels covering the specified range $(80,100$ and $120 \%)$. Accuracy was reported as percent recovery by the assay of known added amount of analyte in the sample (Table 4).

\section{Limits of detection and Limits of quantitation}

According to the ICH recommendations [21], determination of limits of detection and quantitation was based on the standard deviation of the $y$-intercepts of regression lines $(n=3)$ and the slope of the calibration plots (Table 5).

\section{Robustness}

Robustness of an analytical procedure is a measure of its capacity 
Citation: Hafez HM, Abdelaziz LM, Elshanawane AA, Kamal MM (2012) Quantitative Determination of Four Angiotensin-II-Receptor Antagonists in Presence of Hydrochlorothiazide by a Gradient Technique HPLC in their Pharmaceutical Preparations. Pharmaceut Anal Acta 3:167. doi:10.4172/2153-2435.1000167

Page 4 of 7

to remain unaffected by small variations in method parameters and provides an indication of its reliability during normal usage [21]. Robustness was tested by studying the effect of changing mobile phase $\mathrm{pH}$ by \pm 0.1 , the amount of acetonitrile in the mobile phase by $\pm 2 \%$, temperature $\pm 2 \mathrm{C}^{\circ}$, different column and flow rate $\pm 0.05 \mathrm{ml} / \mathrm{min}$ had no significant effect on the chromatographic resolution of the method.

Stability of analytical solution: Also as part of evaluation of robustness, solution stability was evaluated by monitoring the peak area response. Standard stock solutions in methanol were analyzed right after its preparation 1,2 and 3 days after at $5 \mathrm{C}^{\circ}$ and for a day at room temperature. The change in standard solution peak area response over 3 days was $(0.68,0.59,0.64,0.32$ and $0.77 \%)$ for Hydrochlorothiazide, Irbesartan, Losartan potassium, Telmisartan and Valsartan respectively. Their solutions were found to be stable for 3 days at $5 \mathrm{C}^{\circ}$ and for a day at room temperature at least.

\section{Application on pharmaceutical Preparation}

The proposed methods were successfully used to determine
Irbesartan, Losartan potassium, Telmisartan and Valsartan respectively in their dosage forms in presence of Hydrochlorothiazide e.g. X-tension plus tablets, Losazide tablets, Micardis plus tablets, Disartan co tablets respectively. Five replicate determinations were performed. Satisfactory results were obtained for each compound in good agreement with label claims (Table 6 and 7). The results obtained were compared statistically with those from published methods $[5,11,13,16]$ by using Student's t-test and the variance ratio F-test. The results showed that the and $\mathrm{F}$ values were smaller than the critical values. So, there were no significant differences between the results obtained from this method and published methods (Table 8).

\section{Results and Discussion}

\section{Optimization of chromatographic condition}

Several trials were carried out to obtain simple, rapid simultaneous determination for four angiotensin receptor antagonists e.g. Losartan potassium ,Irbesartan, Telmisartan and Valsartan in presence of Hydrochlorothiazide by high performance liquid chromatography

\begin{tabular}{|l|l|l|l|}
\hline Drug name & Average $\mu \mathrm{g} / \mathrm{ml}$ & Average \% & RSD \\
\hline Hydrochlorothiazide & 12.60 & 100.80 & $0.20 \%$ \\
\hline Irbesartan & 150.68 & 100.45 & $0.26 \%$ \\
\hline Losartan potassium & 50.24 & 100.48 & $0.25 \%$ \\
\hline Telmisartan & 80.52 & 100.65 & $0.21 \%$ \\
\hline Valsartan & 80.36 & 100.45 & $0.26 \%$ \\
\hline
\end{tabular}

Table 2: Repeatability of Hydrochlorothiazide, Irbesartan, Losartan potassium, Telmisartan and Valsartan respectively.

\begin{tabular}{|c|c|c|c|c|c|c|}
\hline Drug name & $\begin{array}{l}1^{\text {st }} \text { day } \\
\mu \mathrm{g} / \mathrm{ml}\end{array}$ & $\begin{array}{l}2^{\text {nd } d a y ~} \\
\mu \mathrm{g} / \mathrm{ml}\end{array}$ & $\begin{array}{l}3^{\text {rd day }} \\
\mu \mathrm{g} / \mathrm{ml}\end{array}$ & pooled average & pooled average $\%$ & RSD \\
\hline Hydrochlorothiazide & 12.60 & 12.41 & 12.58 & 12.52 & 100.22 & $0.80 \%$ \\
\hline Irbesartan & 150.68 & 149.51 & 148.59 & 149.59 & 99.73 & $0.70 \%$ \\
\hline Losartan potassium & 50.23 & 49.92 & 49.48 & 49.88 & 99.78 & $0.75 \%$ \\
\hline Telmisartan & 80.52 & 80.00 & 80.18 & 80.23 & 100.29 & $0.32 \%$ \\
\hline Valsartan & 80.36 & 79.86 & 78.91 & 79.71 & 99.60 & $0.92 \%$ \\
\hline
\end{tabular}

Table 3: Intermediate precision of Hydrochlorothiazide, Irbesartan, Losartan potassium, Telmisartan and Valsartan respectively.

\begin{tabular}{|c|c|c|c|c|c|}
\hline Drug name & $\begin{array}{l}\text { Recovery at } 80 \% \text { conc. } \\
(\%)\end{array}$ & $\begin{array}{l}\text { Recovery at } 100 \% \text { conc. } \\
(\%)\end{array}$ & $\begin{array}{l}\text { Recovery at } 120 \% \text { conc. } \\
(\%)\end{array}$ & Average Recovery (\%) & RSD \\
\hline Hydrochlorothiazide & 100.50 & 100.84 & 100.22 & 100.52 & $0.31 \%$ \\
\hline Irbesartan & 100.18 & 100.62 & 100.37 & 100.39 & $0.22 \%$ \\
\hline Losartan potassium & 100.23 & 101.66 & 100.36 & 100.75 & $0.78 \%$ \\
\hline Telmisartan & 101.48 & 100.80 & 99.58 & 100.62 & $0.96 \%$ \\
\hline Valsartan & 100.63 & 100.63 & 100.21 & 100.49 & $0.24 \%$ \\
\hline
\end{tabular}

Table 4: Recovery results for standard solution plus excipients for Hydrochlorothiazide, Irbesartan, Losartan potassium, Telmisartan and Valsartan respectively.

\begin{tabular}{|c|c|c|c|c|c|}
\hline Item & HCTZ & Irbesartan & Losartan & Telmisartan & Valsartan \\
\hline Linear range $(\mu \mathrm{g} / \mathrm{ml})$ & $2.5-15$ & $30-180$ & $10-60$ & $16-96$ & $16-96$ \\
\hline Detection limit $(\mu \mathrm{g} / \mathrm{ml})$ & 0.04 & 0.14 & 0.08 & 0.03 & 0.04 \\
\hline Quantitation limit $(\mu \mathrm{g} / . \mathrm{ml})$ & 0.11 & 0.44 & 0.24 & 0.10 & 0.11 \\
\hline \multicolumn{6}{|l|}{ Regression data } \\
\hline $\mathrm{N}$ & 5 & 5 & 5 & 5 & 5 \\
\hline Slope (b) & 223.09 & 122.54 & 138.95 & 197.86 & 33.45 \\
\hline Standard deviation of the slope & 1.11 & 0.26 & 0.20 & 0.20 & 0.20 \\
\hline Intercept (a) & 4.00 & 0.88 & 9.99 & 120.99 & 122.07 \\
\hline Standard deviation of the intercept & 3.71 & 16.4 & 5.91 & 8.24 & 7.14 \\
\hline Correlation coefficient ${ }^{\circledR}$ & 0.9999 & 1.0 & 1.0 & 0.9997 & 1.0 \\
\hline Standard error of regression & 9.85 & 18.46 & 11.19 & 125.95 & 26.75 \\
\hline
\end{tabular}

$(\mathrm{Y}=\mathrm{a}+\mathrm{bC}$, where $\mathrm{C}$ is the concentration of the compound $(\mu \mathrm{g} / \mathrm{ml})$ and $\mathrm{Y}$ is the drug peak area)

Table 5: Calibration data was resulted from method validation of Hydrochlorothiazide (HCTZ), Irbesartan, Losartan potassium, Telmisartan and Valsartan respectively. 
Citation: Hafez HM, Abdelaziz LM, Elshanawane AA, Kamal MM (2012) Quantitative Determination of Four Angiotensin-II-Receptor Antagonists in Presence of Hydrochlorothiazide by a Gradient Technique HPLC in their Pharmaceutical Preparations. Pharmaceut Anal Acta 3:167. doi:10.4172/2153-2435.1000167

Page 5 of 7

\begin{tabular}{|c|c|c|c|c|c|c|c|c|}
\hline \multirow{2}{*}{$\begin{array}{l}\text { Product name } \\
\text { Drug name }\end{array}$} & \multicolumn{2}{|c|}{$\begin{array}{l}\text { X-tension } \\
\text { plus tablets }\end{array}$} & \multicolumn{2}{|c|}{ Losazide tablets } & \multicolumn{2}{|c|}{ Micardis plus tablets } & \multicolumn{2}{|c|}{ Disartan co tablets } \\
\hline & $\begin{array}{l}\text { IRB } \\
(\%)\end{array}$ & $\begin{array}{l}\text { HCTZ } \\
(\%)\end{array}$ & $\begin{array}{l}\text { LOS } \\
(\%)\end{array}$ & $\begin{array}{l}\text { HCTZ } \\
(\%)\end{array}$ & $\begin{array}{l}\text { TEL } \\
(\%)\end{array}$ & $\begin{array}{l}\text { HCTZ } \\
(\%)\end{array}$ & $\begin{array}{l}\text { VAL } \\
(\%)\end{array}$ & $\begin{array}{l}\text { HCTZ } \\
(\%)\end{array}$ \\
\hline Test 1 & 97.43 & 96.25 & 100.3 & 99.51 & 99.87 & 99.47 & 99.7 & 101.4 \\
\hline Test 2 & 99.22 & 97.53 & 101 & 99.83 & 100.1 & 100.3 & 100.2 & 100.3 \\
\hline Test 3 & 99.34 & 97.63 & 99.35 & 100.2 & 99.66 & 99.49 & 100.2 & 102.1 \\
\hline Test 4 & 100.6 & 98.72 & 100.4 & 99.69 & 99.93 & 100.1 & 100.4 & 100.5 \\
\hline Test 5 & 100.7 & 98.72 & 100.7 & 100.2 & 99.95 & 100.1 & 97.54 & 97.04 \\
\hline SD & 1.33 & 1.02 & 0.62 & 0.31 & 0.16 & 0.39 & 1.19 & 1.94 \\
\hline Average & 99.46 & 97.77 & 100.35 & 99.88 & 99.90 & 99.89 & 99.61 & 100.27 \\
\hline R.S.D & 1.32 & 1.05 & 0.61 & 0.30 & 0.16 & 0.39 & 1.19 & 1.94 \\
\hline
\end{tabular}

Table 6: Results from determination of Irbesartan (IRB), Losartan potassium (LOS), Telmisartan (TEL) and Valsartan (VAL) in presence Hydrochlorothiazide (HCTZ) respectively in their dosage forms by proposed method.

\begin{tabular}{|c|c|c|c|c|c|c|c|c|}
\hline \multirow{2}{*}{$\begin{array}{l}\text { Product name } \\
\text { Drug name }\end{array}$} & \multicolumn{2}{|c|}{$\begin{array}{l}\text { X-tension } \\
\text { plus tablets }\end{array}$} & \multicolumn{2}{|c|}{ Losazide tablets } & \multicolumn{2}{|c|}{ Micardis plus tablets } & \multicolumn{2}{|c|}{ Disartan co tablets } \\
\hline & $\begin{array}{l}\text { IRB } \\
(\%)\end{array}$ & $\begin{array}{l}\text { HCTZ } \\
(\%)\end{array}$ & $\begin{array}{l}\text { LOS } \\
(\%)\end{array}$ & $\begin{array}{l}\text { HCTZ } \\
(\%)\end{array}$ & $\begin{array}{l}\text { TEL } \\
(\%)\end{array}$ & $\begin{array}{l}\text { HCTZ } \\
(\%)\end{array}$ & $\begin{array}{l}\text { VAL } \\
(\%)\end{array}$ & $\begin{array}{l}\text { HCTZ } \\
(\%)\end{array}$ \\
\hline Test 1 & 97.04 & 97.16 & 99.71 & 100.8 & 99.86 & 99.9 & 97.55 & 97.76 \\
\hline Test 2 & 99.44 & 97.88 & 99.98 & 99.65 & 99.8 & 99.88 & 99.93 & 101.9 \\
\hline Test 3 & 99.49 & 97.38 & 99.95 & 99.71 & 100.1 & 99.94 & 100.6 & 101 \\
\hline Test 4 & 99.28 & 99.22 & 100.8 & 100.7 & 99.81 & 100.3 & 100.2 & 102.2 \\
\hline Test 5 & 99.67 & 99.11 & 100.5 & 100.8 & 99.32 & 100.1 & 100.6 & 101.2 \\
\hline SD & 1.1 & 0.96 & 0.45 & 0.60 & 0.28 & 0.18 & 1.28 & 1.78 \\
\hline Average & 98.98 & 98.15 & 100.19 & 100.33 & 99.78 & 100.02 & 99.77 & 100.81 \\
\hline R.S.D & 1.10 & 0.98 & 0.45 & 0.59 & 0.28 & 0.18 & 1.28 & 1.76 \\
\hline Method number & \multicolumn{2}{|l|}{5} & \multicolumn{2}{|l|}{16} & \multicolumn{2}{|l|}{11} & \multicolumn{2}{|l|}{13} \\
\hline
\end{tabular}

Table7: Results from determination of Irbesartan (IRB), Losartan potassium (LOS), Telmisartan (TEL) and Valsartan (VAL) in presence Hydrochlorothiazide (HCTZ) respectively in their dosage forms by reported (published) method.

\begin{tabular}{|c|c|c|c|c|c|}
\hline \multirow{2}{*}{\multicolumn{2}{|c|}{ Drug name }} & \multicolumn{2}{|l|}{ Recovery \pm SD } & \multirow{3}{*}{ 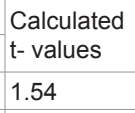 } & \multirow{3}{*}{ 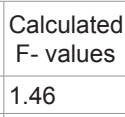 } \\
\hline & & \multirow{2}{*}{$\begin{array}{l}\text { Proposed methods } \\
99.46 \pm 1.33\end{array}$} & \multirow{2}{*}{$\begin{array}{l}\text { Reference method } \\
98.98 \pm 1.10 \\
\end{array}$} & & \\
\hline X-tension plus tablets & IRB (\%) & & & & \\
\hline a-temsiomi pius ladiels & HCTZ (\%) & $97.77 \pm 1.02$ & $98.15 \pm 0.96$ & 2.04 & 1.13 \\
\hline \multirow{2}{*}{ Losazide tablets } & $\operatorname{LOS}(\%)$ & $100.35 \pm 0.62$ & $100.19 \pm 0.45$ & 0.54 & 1.94 \\
\hline & HCTZ (\%) & $99.88 \pm 0.31$ & $100.33 \pm 0.60$ & 1.31 & 0.27 \\
\hline \multirow{2}{*}{ Micardis plus tablets } & TEL (\%) & $99.90 \pm 0.16$ & $99.77 \pm 0.28$ & 0.71 & 0.32 \\
\hline & HCTZ (\%) & $99.89 \pm 0.39$ & $100.02 \pm 0.18$ & 0.82 & 4.74 \\
\hline \multirow{2}{*}{ Disartan co tablets } & VAL (\%) & $99.61 \pm 1.19$ & $99.77 \pm 1.28$ & 0.20 & 0.86 \\
\hline & HCTZ (\%) & $100.27 \pm 1.94$ & $100.81 \pm 1.78$ & 0.41 & 1.20 \\
\hline
\end{tabular}

(Where the Tabulated $t$-values and $F$-ratios at $p=0.05$ are 2.57 and 5.05)

Table 8: Statistical comparison of the proposed and published methods for determination of Irbesartan (IRB), Losartan potassium (LOS), Telmisartan (TEL) and Valsartan (VAL) in presence Hydrochlorothiazide (HCTZ) respectively in their dosage forms by reported method ( $T$ - student test) and (F-test for variance).

(HPLC) method with low cost, simple mobile phase to be safe and more available accessories e.g. detectors and column. Hypersil BDS C-18 $(25 \mathrm{~cm})$ columns were tested for separation using a mobile phase consisted of potassium dihydrogen phosphate buffer $\mathrm{pH}=3.5$ and acetonitrile in different ratio (Figure 4). Different buffers have been also used for good separation between four drugs especially between Valsartan and Irbesartan e.g. ammonium acetate $0.02 \mathrm{M}$ and citrate buffer $0.02 \mathrm{M}$ at the same $\mathrm{pH}=3.5$ adjusting $\mathrm{pH}$ by glacial acetic acid and citric acid respectively (Figure 5).

Controlling mobile phase $\mathrm{pH}$ has important role when analyzing ionizable compounds (Valsartan and telmisartan) by reversed phase (RP) HPLC, it can be recognized and easily understood. In reversed phase HPLC, the retention of analytes is related to their hydrophobicity. The more hydrophobic the analyte, the longer it is retained. When an analyte is ionized, it becomes less hydrophobic and therefore, its retention decreases. Acids lose a proton and become ionized and carry a negative charge when $\mathrm{pH}$ increases (at pH's above the analyte's $\mathrm{pKa}$ ) so behaves as an extremely polar molecule and bases gain a proton and become ionized when $\mathrm{pH}$ decreases (Figure 6) therefore, when separating mixtures containing acids and/or bases by reversed phase HPLC, it is necessary to control the $\mathrm{pH}$ of the mobile phase using an appropriate buffer in order to achieve reproducible results [22,23] Addition of a phosphate buffer at higher $\mathrm{pH}$ eliminated the broad tailing peaks and created rugged conditions suitable for successful assay. In this study, Losartan potassium is ionized compound, Irbesartan is non ionized compound and Valsartan and Telmisartan may be turn to ionizable compound by changing $\mathrm{pH}$ of mobile phase due to presence of carboxylic group (-COOH) in their chemical structure.(Remember: There is a problem in separation between Valsartan and Irbesartan). Trials were carried out under different $\mathrm{pH}$ of phosphate buffer on a Hypersil BDS C-18 $(25 \mathrm{~cm})$ column. At $\mathrm{pH}=2.5$ showed poor separation and long time 17.0 minutes, at $\mathrm{pH}=4.5$ consumed longer time about 
Citation: Hafez HM, Abdelaziz LM, Elshanawane AA, Kamal MM (2012) Quantitative Determination of Four Angiotensin-II-Receptor Antagonists in Presence of Hydrochlorothiazide by a Gradient Technique HPLC in their Pharmaceutical Preparations. Pharmaceut Anal Acta 3:167. doi:10.4172/2153-2435.1000167

22.0 minutes and at $\mathrm{pH}=6.0$ shows good resolution, good separation and shorter time (Figure 7).

As $\mathrm{pH}=6.0$ greater than $\mathrm{pKa}$ of Valsartan by difference equals to 1.1 which enables $(-\mathrm{COOH})$ to give carboxylate anion (-COO-) carrying negative charge so elute rapidly than others. Telmisartan also elute more rapidly than other $\mathrm{pH}$.

The concentration of the mobile phase buffer usually has little effect on retention in reversed phase HPLC, just as long as the buffer concentration is high enough to control $\mathrm{pH}$. A buffer concentration in the range of 25 to $50 \mathrm{mM}$ is adequate for reversed phase applications [23].

Finally, it was found that ACE C-18 column give more good separation and band spacing more than Hypersil BDS C-18 column and sharper peak shape. But for analysis of ARA-II drugs in presence of Hydrochlorothiazide, a new problem is appeared which is interfering between Valsartan and Hydrochlorothiazide .So gradient elution was tried to solve it as in (Figure 2).

\section{Conclusion}

A simple, accurate, precise, robust and reliable LC method has been established for simultaneous determination for Irbesartan, Losartan
A-

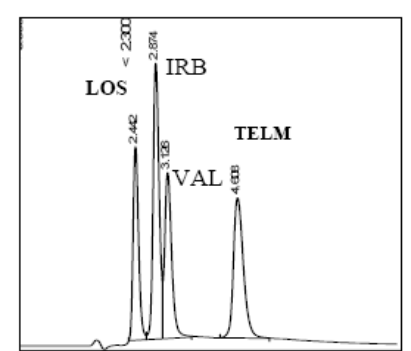

C-

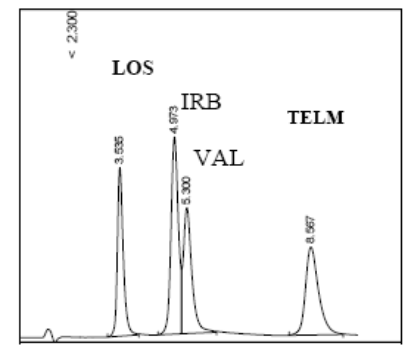

E-

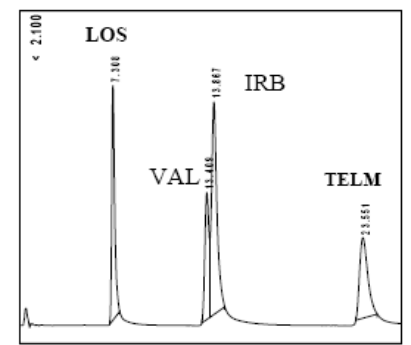

B-

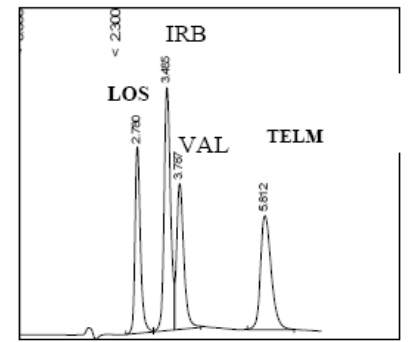

D-

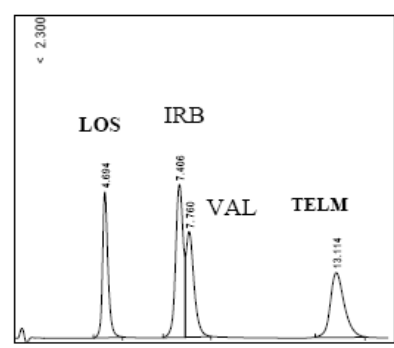

F-

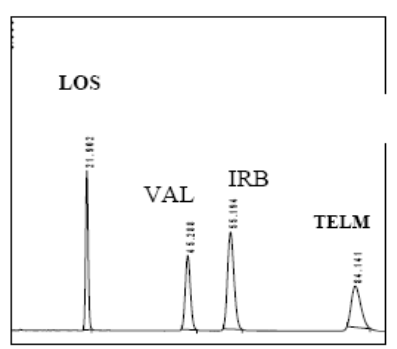

Figure 4: HPLC chromatogram on Hypersil BDS C-18 $(25 \mathrm{~cm})$ Column and mobile phase consisted of $(A)$ acetonitrile and $(B)$ phosphate buffer $\mathrm{pH}=3.5$ in variable ratio where $a-A: B=55: 45$ b- $A: B=50: 50$ c- $A: B=45: 55$ d- $A: B=40: 60$ e- $A: B=35: 65 \mathrm{f}-A: B=25: 75$ for trials to separate Losartan potassium(LOS), Irbesartan (IRB), Valsartan (VAL) and Telmisartan (TELM) respectively. a- Ammonium acetate buffer:

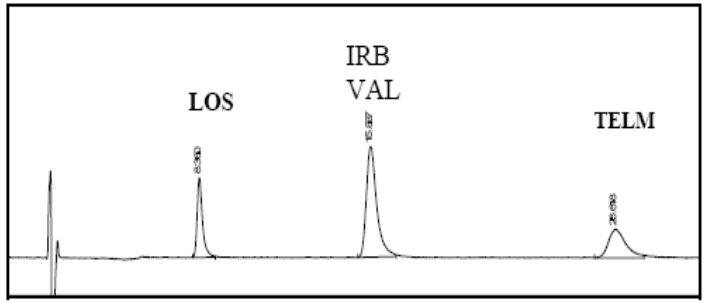

b- Citrate buffer

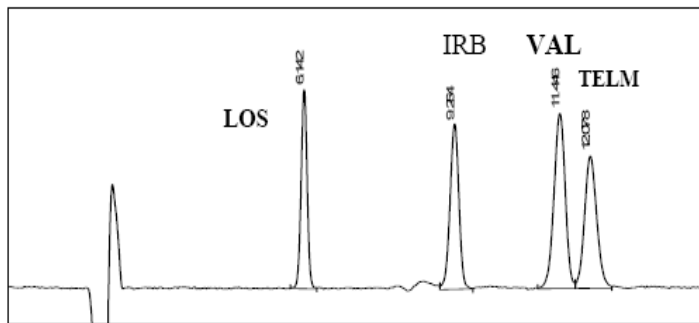

Figure 5: HPLC chromatogram of Hypersil BDS C-18 $(25 \mathrm{~cm})$ Column and mobile phase consisted of $(A)$ acetonitrile and $(B)$ buffer $\mathrm{pH}=3.5$ in ratio $35: 65 \%$ where a- ammonium acetate $0.02 \mathrm{M}$ b- citrate buffer $0.02 \mathrm{M}$ for trials to separate Losartan potassium(LOS), Irbesartan (IRB), Valsartan (VAL) and Telmisartan (TELM) respectively.

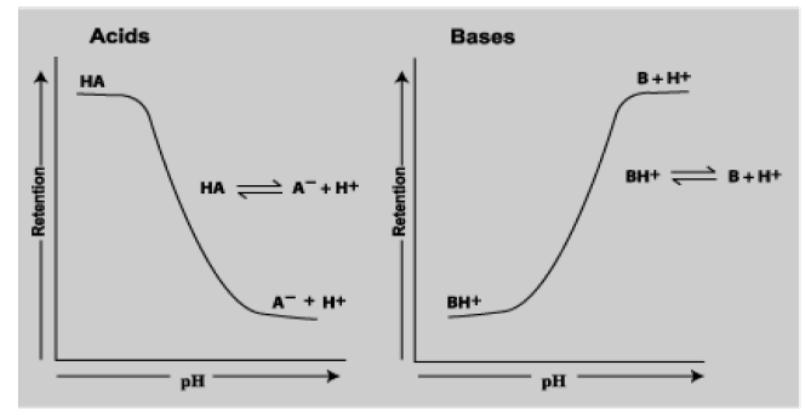

As acids lose a proton and become ionized (with increasing $p H$ ), their retention decreases. As bases gain a proton and become ionized (with decreasing $p H$ ) their retention decreases. Figure 6: Effect of $\mathrm{pH}$ on the retention of acids and bases in reversed phase HPLC.

potassium, Telmisartan, Valsartan in presence of Hydrochlorothiazide in their formulations. The method has several advantages:

1. The first is using HPLC-UV which is the most available instrument in pharmaceutical analysis in companies due to its low cost in comparison with methods utilized electrophoresis, HPLC coupling with fluorimetric detection or mass spectroscopy.

2. High sensitive method has LOD range $(0.04-0.14) \mu \mathrm{g} / \mathrm{ml}$ and LOQ range (0.1-0.44) $\mu \mathrm{g} / \mathrm{ml}$.

3. It is suitable for analysis of antihypertensive agents in their formulations in a single run, in contrast with previous methods. This makes the method suitable for routine analysis in quality-control laboratories. Other merits are rapid analysis, a simple mobile phase, simple sample preparation, does not use polluting reagents.

4. Illustration of steps of developing validated HPLC method 
Citation: Hafez HM, Abdelaziz LM, Elshanawane AA, Kamal MM (2012) Quantitative Determination of Four Angiotensin-II-Receptor Antagonists in Presence of Hydrochlorothiazide by a Gradient Technique HPLC in their Pharmaceutical Preparations. Pharmaceut Anal Acta 3:167. doi:10.4172/2153-2435.1000167

a- Phosphate buffer $\mathrm{pH}=2.5$ :

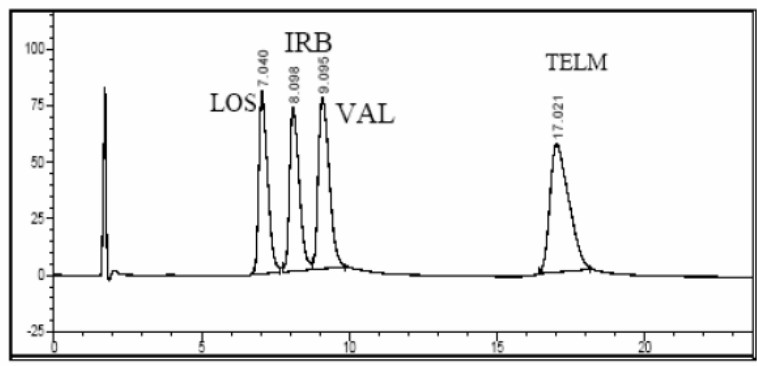

2- Phosphate buffer $\mathrm{pH}=4.5$

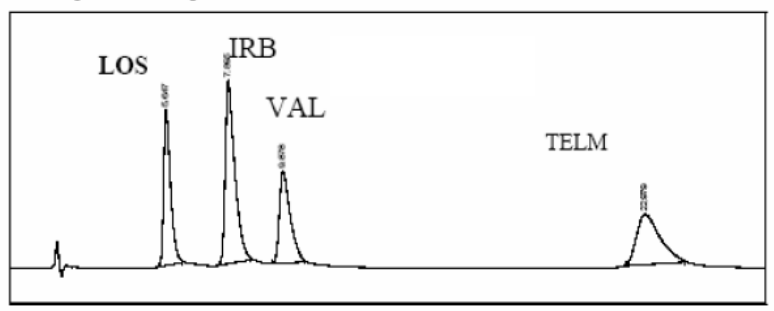

3- Phosphate buffer $\mathrm{pH}=6$.

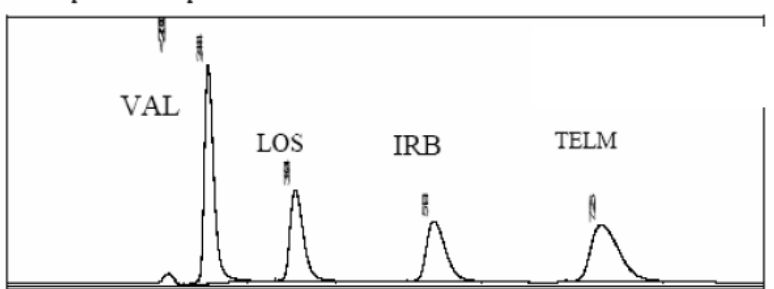

Figure 7: HPLC chromatogram of Hypersil BDS C-18 $(25 \mathrm{~cm})$ Column and mobile phase consisted of (A) acetonitrile and (B) phosphate buffer in ratio $35: 65 \%$ where $\mathrm{a}-\mathrm{pH}=2.5 \mathrm{~b}-\mathrm{pH}=4.5 \mathrm{c}-\mathrm{pH}=6.0$ for trials to Losartan potassium(LOS), Irbesartan (IRB), Valsartan (VAL) and Telmisartan (TELM) respectively.

depending on physicochemical properties of drugs especially solubility and $\mathrm{pKa}$ of drugs.

\section{References}

1. Gonzalez L, Lopez JA, Alonso RM, Jimenez RM (2002) Fast screening method for the determination of angiotensin II receptor antagonists in human plasma by high performance liquid chromatography with fluorimetric detection. J Chromatogr A 949: 49-60.

2. Ferreirósa N, Iriartea G, Alonso RM, Jiméneza RM (2007) Development of a solid phase extraction procedure for HPLC-DAD determination of several angiotensin II receptor antagonists in human urine using mixture design. Talanta 73: 748-756.

3. Health wise Knowledgebase (2011) US Pharmacopoeia, Rockville.

4. British Pharmacopoeia, London (2011) with the monographs of the sixth edition of the European pharmacopoeia monograph

5. Rane VP, Patil KR, Sangshetti JN, Yeole RD, Shinde DB (2010) Stability indicating LC method for simultaneous determination of irbesartan and hydrochlorothiazide in pharmaceutical preparations. J Chromatogr Sci 48: 595600.

6. Tutunji LF, Tutunji MF, Alzoubi MI, Khabbas MH, Arida Al (2010) Simultaneous determination of irbesartan and hydrochlorothiazide in human plasma using HPLC coupled with tandem mass spectrometry: Application to bioequivalence studies. J Pharm Biomed Anal 51: 985-990.

7. Erk N (2003) Simultaneous determination of irbesartan and hydrochlorothiazide in human plasma by liquid chromatography. J Chromatogr B Analyt Technol Biomed Life Sci 784: 195-201.

8. McCarthy KE, Wang Q, Tsai EW, Gilbert RE, Ip DP, et al. (2007) Determination of Losartan and its degradates in Cozaar ${ }^{\circledR}$ tablets by reversed-phase high- performance thin-layer chromatography. J Pharm Biomed Anal 17: 671-677.

9. Obando MA, Estela JM, Cerda V (2008) Multi-syringe chromatography (MSC) system for the on-line solid-phase extraction and determination of hydrochlorothiazide and losartan potassium in superficial water. J Pharm Biomed Anal 48: 212-217.

10. Quagli MG, Donati E, Carlucci G, Mazzeo P, Fanali S (2002) Determination of losartan and hydrochlorothiazide in tablets by CE and CEC. J Pharm Biomed Anal 29: 981-987.

11. Wankhede SB, Tajne MR, Gupta KR, Wadodkar SG (2007) RP-HPLC method for simultaneous estimation of telmisartan and hydrochlorothiazide in tablet dosage form. Ind J Pharm Sci 69: 298-300.

12. Bebawy LI, Abbas SS, Fattah LA, Refaat HH (2005) Application of first-derivative ratio derivative spectrophotometry, TLC-densitometry and spectrofluorimetry for the simultaneous determination of telmisartan and hydrochlorothiazide in pharmaceutical dosage forms and plasma. II Farmaco 60: 859-867.

13. Satana E, Altinay S, Göger NG, Özkan SA, sentürk Z (2001) Simultaneous determination of valsartan and hydrochlorothiazide in tablets by first-derivative ultraviolet spectrophotometry and LC. J Pharm Biomed Anal 25: 1009-1013.

14. Liu F, Zhang J, Gao S, Guo Q (2008) Simultaneous Determination of Hydrochlorothiazide and Valsartan in Human Plasma by Liquid Chromatography/ Tandem Mass Spectrometry. Analytical Letters 41:1348-1365.

15. Lia H, Wang Y, Jiang Y, Tang $Y$, Wang J, et al. (2007) A liquid chromatography/ tandem mass spectrometry method for the simultaneous quantification of valsartan and hydrochlorothiazide in human plasma. J Chromatogr B Analyt Technol Biomed Life Sci 852: 436-442.

16. Hamdy Z, Youssef A Specification of Losazide tablets (Losartan potassium and hydrochlorothiazide) Egyptian international pharmaceutical industry company. M.O.H. (Egypt) NO: 24522/2006.

17. Hillaert S, Van den Bossche W (2002) Optimization and validation of a capillary zone electrophoretic method for the analysis of several angiotensin-II-receptor antagonists. J Chromatogr A 979: 323-333.

18. Hillaert S, De Beer TRM, De Beer JO, Van den Bossche W (2003) Optimization and validation of a micellar electrokinetic chromatographic method for the analysis of several angiotensin-II-receptor antagonists. J Chromatogr A 984: $135-146$.

19. Kristoffersen L, Øiestad EL, Opdal MS, Krogh M, Lundanes E, Christophersen AS (2007) Simultaneous determination of 6 beta-blockers, 3 calciumchannel antagonists, 4 angiotensin-II antagonists and 1 antiarrhytmic drug in post-mortem whole blood by automated solid phase extraction and liquid chromatography mass spectrometry, Method development and robustness testing by experimental design. J Chromatogr B 850:147-160.

20. Hillaert S, Van den Bossche W (2007) Simultaneous determination of hydrochlorothiazide and several angiotensin-II-receptor antagonists by capillary electrophoresis. J Pharm Biomed Anal 31: 329-339.

21. ICH Harmonized Tripartite Guideline, Validation of Analytical Procedures: Text and Methodology Q2 (R1).

22. Heyrman AN, Henry RA, http://www.hplcsupply.com /pdf/App_9.pdf.

23. Preparing Buffered Mobile Phases for Reversed Phase HPLC. 